\title{
Nutritional indices and biochemical profile of Helicoverpa armigera [Hübner (1808)] on different groundnut genotypes
}

\author{
Abdul Rasheed WAR ${ }^{1,2}$, Barkat HUSSAIN ${ }^{3}$, Suraj Prashad MISHRA ${ }^{1}$, Rajendra S MUNGHATE ${ }^{1}$, Hari C \\ SHARMA ${ }^{1,}$
}

Received August 20, 2020; accepted December 09, 2020. Delo je prispelo 20. avgusta 2020, sprejeto 09. decembra 2020.

Nutritional indices and biochemical profile of Helicoverpa armigera [Hübner (1808)] on different groundnut genotypes

Abstract: Nutritional indices and biochemical profile of Helicoverpa armigera in response to feeding on different groundnut genotypes was studied. The moderately resistant genotypes were ICGV 86699, ICGV 86031, ICG 2271 and ICG 1697. JL 24 was used as the susceptible check. Consumption index (CI), approximate digestibility (AD), efficiency of conversion of ingested food (ECI) and efficiency of conversion of digested food (ECD) were recorded. In addition, the activities of digestive and defensive enzymes of $H$. armigera were studied. H. armigera larvae showed significantly lower CI, AD, ECI and EDI when fed on moderately resistant genotypes than the insects fed on JL 24. Serine protease and trypsin activities were low in insects fed on resistant genotypes than the ones fed on JL 24. Further, insects fed on resistant genotypes showed significantly greater glutathione-S-transferase activity than the insects fed on JL 24. A reverse trend was observed for esterase activity. Similar trend was observed for total protein content of the insects. Thus, nutritional quality of host plants affects insect's physiology and could be used as an important indicator of host plant resistance against insect pests and to understand the adaptation of insect pests, if any, to various genotypes/host plants.

Key words: Host plant resistance; nutritional indices; digestive enzymes; groundnut; Helicoverpa
Prehranjevalni indeksi in biokemični profil južne plodovrtke, Helicoverpa armigera [Hübner (1808)], na različnih genotipih arašidov

Izvleček: V raziskavi so bili preučevani prehranjevalni indeksi in biokemični profil južne plodovrtke (Helicoverpa armigera) kot odziv na prehranjevanje na različnih genotipih arašidov. Zmerno odporni genotipi arašidov so bili ICGV 86699 , ICGV 86031, ICG 2271 in ICG 1697. Genotip JL 24 je bil uporabljen kot občutljiva kontrola. Določeni so bili prehrambeni indeks (CI), navidezna prebavljivost (AD), učinkovitost pretvorbe pojedene hrane (ECI) in učinkovitost pretvorbe prebavljene hrane (ECD). Dodatno so bile v škodljivcu preučene aktivnosti prebavnih in obrambnih encimov. Gosenice južne plodovrtke so imele značilno manjše vrednosti parametrov kot so $\mathrm{CI}, \mathrm{AD}, \mathrm{ECI}$ in EDI, kadar so se hranile na zmerno odpornih genotipih $\mathrm{v}$ primerjavi s tistimi, ki so se hranile na občutljivem genotipu JL 24. Aktivnosti serin proteaze in tripsina so bile manjše pri žuželkah, ki so se hranile na odpornih genotipih v primerjavi s tistimi, ki so se hranile na občutljivem 'JL 24'. Žuželke, ki so se hranile na odpornih genotipih so imele značilno večjo aktivnost glutation-S-transferaze kot žuželke, ki se hranile na 'JL 24'. Nasproten trend je bil opažen v aktivnosti esterase. Podoben trend je bil ugotovljen v vsebnosti celokupnih beljakovin v žuželkah. Hranilna kakovost gostiteljskih rastlin vpliva na fiziologijo škodljivih žuželk in bi jo lahko uporabili kot pomemben kazalnik odpornosti gostiteljskih rastlin proti škodljivim žuželkam. S tem bi razumeli prilagoditve škodljivih žuželk na različne genotipe gostiteljskih rastlin.

Ključne besede: odpornost gostiteljskih rastlin; prehranjevalni indeksi; prebavni encimi; arašidi; Helicoverpa

1 International Crops Research Institute for the Semi-Arid Tropics (ICRISAT), Patancheru, Telangana, India

2 Corresponding author, e-mail: abdulwar2@gmail.com

3 Sher-e-Kashmir University of Agricultural Sciences and Technology (SKUAST-K), Shalimar, Srinagar, Jammu and Kashmir, India

The study in this manuscript is part of the Ph.D. research work of the Abdul Rasheed WAR (Mentor-Hari C SHARMA) 


\section{INTRODUCTION}

Plants face innumerable challenges from biotic and abiotic stresses, however, biotic stress by insect pests is one of the major stresses the plants face and take a heavy toll on crop yields. Though synthetic insecticides are the main insect pest controlling methods in many crops, they pose a great threat to the non-target organisms. For example, pesticide resistance is developed by insects, pest-resurgence, pesticide residues in food and health hazards in human beings (Isman, 2006; Sharma, 2007). Therefore, there is a need for an alternative environmentally safe crop protection technologies for safe and sustainable crop production. Breeders and entomologists have been developing insect resistant crop cultivars that could withstand insect pressure (Sharma et al., 2003; Smith, 2005; Sharma, 2009; Nair et al., 2020). Groundnut (Arachis hypogaea L.) is one of the important oilseed crops across the tropical and subtropical regions. Groundnut crop is affected by a number of biotic and abiotic stresses. Insect pests are the major biotic constraints of groundnut. The economically important insect pests of groundnut include western flower thrips (Frankliniella occidentalis Pergande, 1895 and melon thrips (Thrips palmi Karny, 1925); leaf miners (Aproaerema modicella [Deventer, 1904]); aphids (Aphis craccivora Koch, 1854); leafhoppers (Empoasca dolichi Paoli, 1930); white grubs (Holotrichia consanguinea Blanchard, 1850); pod borer, Helicoverpa armigera (Hübner(1808)) and armyworm, Spodoptera litura (Fabricius, 1775) (Sharma et al., 2003).

Helicoverpa. armigera (Hübner,[1808]) is a polyphagous lepidopteran pest with wide distribution across Asia, Africa, Australia and southern Europe (Sharma et al., 2003; Sharma, 2005). It causes severe damage to cereals, fruit crops, cash crops, vegetables including groundnut. Host plant resistance plays an important role to ward of insect pests by plants (Howe \& Jander, 2008; War et al., 2011). It is a simple, inbuilt and eco-friendly method of managing insect pests (Sharma \& Ortiz, 2002; War et al., 2012). Plant defensive traits interfere with host plant selection by the insect pest, deter the insects by producing volatile compounds or by averting oviposition by the insects. Plant defense against insect pests is manifested through morphological (surface wax, lignification, spines, hairs and sclerophylly) and biochemical traits (Dwivedi et al., 1986; Sharma et al., 2009; He et al., 2011; War et al., 2012; Bohinc et al., 2013). Biochemical traits constitute toxic secondary metabolites as a major component of plant defese against insect pests. They are directly toxic to insect pests or recruit the natural enemies of the insect pests (Howe \& Jander, 2008; Karban, 2011; War et al., 2011, 2013). In groundnut, toxic secondary metabolites have been reported to hamper growth and development of insect pests (Stevenson et al., 1993; Senguttuvan \& Sujatha, 2000; War et al., 2013, 2014).

Several reports have shown the role of plant toxic metabolites affecting insect growth and development. For example, Rao et al. (1998) showed that polyphenols in groundnut plants provide resistance against leaf miner A. modicella. Further, plant secondary metabolites such as dihydroxybenzoic acid, vanillic acid, caffeic acid and umbelliferone have been suggested to be involved in resistance against insect pests (War et al., 2016). In groundnut, structural (trichomes) and biochemical traits (phenols, tannins and defensive proteins) are involved in defense against insect pests including $H$. armigera (War et al., 2013, 2016; War \& Sharma, 2014). Similarly, Stevenson et al. (1993) reported that in groundnut, plant toxins such as caffeoylquinic acids, quercetin, and diglycosides are the main contributors of insect resistance. They found that chlorogenic acid and rutin are also involved in resistance against $S$. litura. To test the hypothesis that insect resistant plants contain plant defensive traits that affect the insect growth and development by interfering with the nutritional indices of the insects, consumption, digestion and utilization of food and also the biochemical traits of $H$. armigera larvae were studied after feeding on the insect resistant and susceptible groundnut genotypes.

\section{MATERIALS AND METHODS}

\subsection{CHEMICALS}

The chemicals used were of analytical grade. Ethylene diamine tetra acetic acid (EDTA), tannic acid, trypsin inhibitor, bovine serum albumin, 1-napthol, glycine, 4-chloronapthol, disodium hydrogen phosphate, sodium dihydrogen phosphate, N-a-Benzoyl-DL-arginine $\mathrm{p}$ nitroanilide (BApNA), glucose, GSH, sodium hydroxide, and sodium carbonate $\left(\mathrm{Na}_{2} \mathrm{CO}_{3}\right)$ were procured from Sigma Aldrich (St Louis, Missouri). Acetic acid and 1-chloro-2, 4-dinitrobenzene (CDNB) were obtained from Sisco Research Laboratory (India) and HiMedia Pvt. Ltd (India), respectively.

\subsection{HELICOVERPA ARMIGERA}

Helicoverpa armigera larvae were collected from the field at International Crops Research Institute for the Semi-Arid Tropics (ICRISAT), Patancheru, Telangana, India $\left(17^{\circ} 25^{\prime} \mathrm{N}\right.$ latitude, $78^{\circ} 00^{\prime} \mathrm{E}$ longitude and 545 m.a.s.l.). The field collected insects were reared for one generation on the natural host under laboratory conditions before mixing with the laboratory culture. Under 
laboratory conditions, insects were reared on chickpea based artificial diet (Table 1, Armes et al., 1992). The pupae were disinfected in $2 \%$ sodium hypochlorite solution before transferring them to plastic jars containing Vermiculite for adult emergence. Newly emerged adults were immediately transferred to the wooden oviposition cages $(30 \times 30 \times 30 \mathrm{~cm})$ containing $10 \%$ honey or sucrose solution in a cotton swab as food. Eggs were collected on rough surfaces of diaper liners $(5 \times 15 \mathrm{~cm})$ and thin cotton wool sheets hung inside the cage. The eggs laid on the liners sterilized in $2 \%$ sodium hypochlorite solution. The liners were dried and placed inside the plastic cups. The newly emerged larvae were reared initially in groups of 200 to 250 for five days in $200 \mathrm{ml}$ plastic cups containing 2 to $3 \mathrm{~mm}$ layer of artificial diet on the bottom and sides. To avoid cannibalism, the larvae were reared individually in six cells well plates, of which each cell well was 3.5 $\mathrm{cm}$ in diameter and $1.5 \mathrm{~cm}$ in depth. The cell wells were filled with $7 \mathrm{ml}$ diet for larval development until pupation. After every six months, the laboratory culture was mixed with the field-collected insects to maintain culture heterogeneity. Newly emerged larvae were used for the experiments.

\subsection{GROUNDNUT PLANTS}

The groundnut genotypes used in this study included four moderate to high levels of insect resistant cultivars (ICGV 86699, ICGV 86031, ICG 2271 and ICG
1697) and a susceptible check (JL 24) (Sharma et al., 2003). The groundnut plants were grown in plastic pots (30 cm diameter and $40 \mathrm{~cm}$ deep) containing soil, sand, and farmyard manure (2:1:1 ratio) in a greenhouse at ICRISAT, Patancheru, Telangana, India. The plants were watered as needed and were maintained as per good agricultural practices. Five seeds were sown and later two seedlings were retained in each pot for the experimental purpose at 10 days after seedling emergence. The temperature and relative humidity were maintained at 26 $\pm 5^{\circ} \mathrm{C}$ and $65+5 \%$, respectively, using desert coolers. Leaves (first fully expanded tetrafoliates) from 20-days old plants were used for the experiments.

\subsection{CONSUMPTION, DIGESTION AND UTILIZA- TION OF FOOD BY HELICOVERPA ARMIG- ERA}

The detached leaf assay technique described by Sharma et al. (2005) was followed to study consumption, digestion and utilization of food by $H$. armigera. The leaves were brought from glasshouse to lab in ice box. In each $100 \mathrm{ml}$ plastic cup, a single tetrafoliate was embedded in $3 \%$ agar-agar. Third-instar larvae of similar size were starved for $4 \mathrm{~h}$ before releasing on the leaves and a single larva was released on one tetrafoliate. After 5 days of feeding, larval mass, leaf damage rating, and dry mass of the residual food was recorded. To calculate the dry mass of the introduced food, fresh mass of the

Table 1: Composition of semi-synthetic diet for Helicoverpa armigera

\begin{tabular}{lll}
\hline Diet component & Ingredients & Quantity (g) per 1,000 ml diet \\
\hline Part A & Chickpea flour & 300 \\
& Sorbic acid & 3.0 \\
& Methyl-p-hydroxybenzoate & 5.0 \\
& Ascorbic acid & 4.7 \\
& Yeast & 48 \\
& Aureomycin powder & 11.5 \\
& Cholesterol & 1.5 \\
& Formaldehyde (1\%) & $20 \mathrm{ml}$ \\
& Multivitamin solution (A,B,D,E,C) drops & $10 \mu \mathrm{l}$ \\
& Water & $450 \mathrm{ml}$ \\
Part B & Agar-agar & 17.3 \\
& Water & $800 \mathrm{ml}$ \\
\hline
\end{tabular}

Diet preparation: The diet was prepared as follows:

1. Measured quantities of part A were mixed.

2. Agar-agar was added to water in a separate container and boiled for $5 \mathrm{~min}$ (Part B).

3. Part A and Part B were mixed thoroughly in a blender to get an even consistency.

4. The diet was poured into small plastic cups and allowed to cool under a laminar flow for 1 to $2 \mathrm{~h}$. 
food remaining after larval consumption was multiplied by a standard factor determined by maintaining an aliquot of the food under similar conditions in the absence of larvae, weighing it, then drying and reweighing it. The dry and fresh mass of aliquots were used to determine the percentage dry matter. The dry mass was expressed as the percentage dry matter in each genotype. The unconsumed food and frass from each detached leaf assay were removed, weighed and dried at $65^{\circ} \mathrm{C}$ for $72 \mathrm{~h}$ in a hot-air oven. The dry mass of the food unconsumed by the insects was calculated as the difference between the dry mass of the unconsumed food and the calculated dry mass of the offered food. The difference between the mass of the larvae before and after the feeding period was taken as the larval mass gain.

The nutritional indices such as food consumption, digestion, and efficiency of conversion of the ingested food into body matter were calculated as per Waldbauer (1968) and Sharma \& Franzmann (2000).

The consumption index (CI) was calculated as:

$$
C I=\frac{\text { Mass of food ingested }}{\text { Duration of feeding period } X \text { Mean mass of insect }} \times 100
$$

Approximate digestibility (AD) of food was calculated as follows:

$$
A D=\frac{\text { Mass of food ingested }- \text { Mass of frass }}{\text { Mass of food ingested }} \times 100
$$

Efficiency of conversion of ingested food into body matter (ECI) was calculated as follows:

$$
E C I=\frac{\text { Mass gained by the larva }}{\text { Mass of food ingested }} \times 100
$$

Efficiency of conversion of digested food (ECD) was calculated as:

$$
E C D=\frac{\text { Mass gained by the larva }}{\text { Mass of food ingested }- \text { Mass of frass }} \times 100
$$

\subsection{BIOCHEMICAL TRAITS OF INSECT PESTS}

\subsubsection{Total serine protease assay}

Insects from the bioassay cups were collected after 5 days of the infestation and dissected. The midguts of the larvae were extracted in in $0.2 \mathrm{M}$ sodium phosphate buffer $(\mathrm{pH}$ 7.5) and homogenized in $0.1 \mathrm{M}$ glycine- $\mathrm{NaOH}$ buffer ( $\mathrm{pH} 10)$, containing $1 \mathrm{mM}$ EDTA. The filtrate was passed through three-layered cheese cloth and centrifuged at $10,000 \mathrm{rpm}$ for $20 \mathrm{~min}$ at $4{ }^{\circ} \mathrm{C}$. A separate tube was used to collect the supernatant to be used as source for determining the enzyme activity. For the estimation of serine protease activity, azocasein was used as a substrate (Hegedus et al., 2003). To midgut supernatant (0.04 ml), 0.3 $\mathrm{ml}$ of $1 \%$ azocasein solution that was prepared in $0.05 \mathrm{M}$ glycine- $\mathrm{NaOH}$ buffer ( $\mathrm{pH} 10)$ was added. The solution was incubated at $28{ }^{\circ} \mathrm{C}$ for $15 \mathrm{~min}$. To the reaction mixture, $0.34 \mathrm{ml}$ of $10 \%$ TCA was added and then incubated for 1 $\mathrm{h}$ at room temperature. After centrifugation at $12,000 \mathrm{rpm}$ for $10 \mathrm{~min}, 0.68 \mathrm{ml}$ of $1 \mathrm{M} \mathrm{NaOH}$ was added to the supernatant. The absorbance was read at $495 \mathrm{~nm}$ and total midgut serine protease activity (SP) was calculated as follows:

$$
S P=\frac{A b s(\text { sample })-A b s(\text { blank })}{\text { Incubation time }(\text { min })} \times 1000
$$

The total serine protease activity was expressed as tryptic activity $(\mathrm{mU})$ per min of incubation per $\mathrm{mg}$ insect protein ( $\mathrm{mU} \mathrm{min} \mathrm{mg}^{-1} \mathrm{mg}^{-1}$ protein).

\subsubsection{Trypsin assay}

Trypsin activity was determined as per Perlmann \& Lorand (1970). To the midgut extract of $0.15 \mathrm{ml}, 1 \mathrm{ml}$ of 1 mM BApNA (in $0.2 \mathrm{M}$ glycine- $\mathrm{NaOH}$ buffer, $\mathrm{pH} 10$ ), was added. The reaction mixture was incubated at $37{ }^{\circ} \mathrm{C}$ for $10 \mathrm{~min}$. The reaction was terminated by adding $0.2 \mathrm{ml}$ of $30 \%$ acetic acid and the absorbance was read at $410 \mathrm{~nm}$. The unit $1 \mathrm{~mol} \mathrm{~min}^{-1} \mathrm{mg}^{-1}$ protein was used to express the trypsin activity.

\subsubsection{Esterase (est) assay}

For determination of esterase (EST) and glutathioneS-transferase assay (GST) activities, similar procedure was followed for extraction by dissecting the larvae in $0.1 \mathrm{M}$ sodium phosphate buffer ( $\mathrm{pH} 7.5$ ). Homogenization of midguts was carried out in $0.1 \mathrm{M}$ sodium phosphate buffer ( $\mathrm{pH}$ 7.5) containing $1 \mathrm{mM}$ EDTA. The filtrate was passed through three-layered cheese cloth and centrifuged for 15 $\min \left(4^{\circ} \mathrm{C}\right)$ at $12,000 \mathrm{rpm}$. The supernatant was used for the estimation of EST and GST activities. The EST activity was estimated by adding $0.1 \mathrm{ml}$ enzyme sample diluted 10 times with $0.1 \mathrm{M}$ sodium phosphate buffer to $1.5 \mathrm{mM}$ 1-naphthyl acetate solution. The reaction mixture was incubated at for $30 \mathrm{~min}$ at $25^{\circ} \mathrm{C}$ and the reaction was stopped by adding Fast Blue B (in $5 \%$ SDS) staining solution. The absorbance was read at $490 \mathrm{~nm}$ after $15 \mathrm{~min}$ of addition of the stopping solution. The hydrolysed substrate concentration was determined from the standard curve of 1-naphthol. The EST specific activity was expressed as $1 \mathrm{~mol}$ of 1-naphthol formed $\mathrm{min}^{-1} \mathrm{mg}^{-1}$ protein.

\subsubsection{Glutathione-s-transferase (gst) assay}

The GST activity was estimated by using 1-chlo- 
ro-2,4-dinitrobenzene (CDNB) and reduced GSH as substrates (Habig et al., 1974). To $1 \mathrm{ml}$ of phosphate buffer ( $\mathrm{pH} 7.5), 0.1 \mathrm{ml}$ of CDNB $(25 \mathrm{mM})$ and $1.6 \mathrm{ml}$ of distilled water were added. To this mixture, $0.1 \mathrm{ml}$ of 10 fold enzyme solution diluted with $0.1 \mathrm{M}$ sodium phosphate buffer $(\mathrm{pH} 7.5)$ was added. The reaction mixture was incubated for $5 \mathrm{~min}$ at $37^{\circ} \mathrm{C}$ and $0.1 \mathrm{ml}$ of $20 \mathrm{mM} \mathrm{GSH}$ was added. Absorbance was read for $3 \mathrm{~min}$ at $30 \mathrm{~s}$ interval at $340 \mathrm{~nm}$. The CDNB extinction coefficient of $9.6 \mathrm{mM} \mathrm{cm}^{-1}$ was used in calculating the enzyme activity. The specific activity of GST was expressed as nmol of CDNB conjugate formed $\mathrm{min}^{-1} \mathrm{mg}^{-1}$ protein.

\subsubsection{Estimation of protein content}

Total protein content of the insects fed on groundnut genotypes was determined by Lowery's method (Lowry et al., 1951). The bovine serum albumin was used as a standard and the protein content was expressed as $\mathrm{mg} \mathrm{g}^{-1}$ body mass.

\subsection{STATISTICAL ANALYSIS}

The data was analysed through analysis of variance

(ANOVA) using SPSS v15.1 (SPSS, Inc., Chicago, IL, USA). The significant effects of the treatment $(p \leq 0.05)$ were separated by the Tukey's test.

\section{RESULTS}

\subsection{FOOD CONSUMPTION AND UTILIZATION BY Helicoverpa armigera}

The insects fed on genotypes ICGV 86699, ICGV 86031, ICG 2271 and ICG 1697 showed significantly lower CI per unit body mass than the insects on the susceptible check, 'JL 24' (Table 2). Similarly, the insects fed on insectresistant genotypes, ICGV 86699, ICGV 86031, ICG 1697 and ICG $2271(36.5-45.4 \%)$ had lower AD than those fed on 'JL 24 ' (67.5 \%). Further, ECI was significantly lower in larvae fed on genotypes ICGV 86699, ICGV 86031, ICG 2271 and ICG $1697(21.3-28.2 \%)$ than those fed on the susceptible check, 'JL 24' (54.1\%). The ECD in insects fed on the insect-resistant genotypes varied from 23.6 $30.2 \%$, while the larvae fed on 'JL 24' showed a high ECD (45.7\%).

\subsection{ENZYMES}

Table 2: Nutritional indices of Helicoverpa armigera larvae fed on groundnut genotypes

\begin{tabular}{lllll}
\hline & \multicolumn{3}{c}{ Nutritional indices } \\
\cline { 2 - 5 } Genotypes & CI (mg/mg/day) & AD $(\%)$ & ECI $(\%)$ & ECD (\%) \\
\hline ICGV 86699 & $2.3 \pm 0.01^{\mathrm{bc}}$ & $36.5 \pm 3.8^{\mathrm{c}}$ & $21.3 \pm 1.5^{\mathrm{b}}$ & $27.1 \pm 1.3^{\mathrm{bc}}$ \\
ICGV 86031 & $2.6 \pm 0.03^{\mathrm{bc}}$ & $41.2 \pm 2.3^{\mathrm{b}}$ & $25.5 \pm 1.2^{\mathrm{b}}$ & $23.6 \pm 1.4^{\mathrm{bc}}$ \\
ICG 2271 & $3.5 \pm 0.02^{\mathrm{b}}$ & $44.3 \pm 2.9^{\mathrm{b}}$ & $28.2 \pm 1.8^{\mathrm{b}}$ & $30.2 \pm 2.5^{\mathrm{b}}$ \\
ICG 1697 & $2.9 \pm 0.01^{\mathrm{b}}$ & $45.4 \pm 3.0^{\mathrm{b}}$ & $24.7 \pm 1.9^{\mathrm{b}}$ & $29.3 \pm 2.2^{\mathrm{b}}$ \\
JL 24 & $4.1 \pm 0.04^{\mathrm{a}}$ & $67.5 \pm 3.7^{\mathrm{a}}$ & $54.1 \pm 2.3^{\mathrm{a}}$ & $45.7 \pm 2.7^{\mathrm{a}}$ \\
\hline
\end{tabular}

Within columns, (means $\pm \mathrm{SD}$ ) followed by same letter(s) do not differ significantly (Tukey's HSD test, $p<0.05)$. CI $=$ Consumption index, AD = Approximate digestibility, ECI = Efficiency of conversion of ingested food and ECD = Efficiency of conversion of digested food.

Table 3: Total serine protease and trypsin activities of Helicoverpa armigera larvae fed on resistant and susceptible groundnut genotypes

\begin{tabular}{lll}
\hline Genotypes & $\begin{array}{l}\text { Serine protease } \\
\left(\mathrm{mU} \mathrm{min}^{-1} \mathrm{mg}^{-1} \text { protein }\right)\end{array}$ & $\begin{array}{l}\text { Trypsin } \\
\left(\mu \mathrm{mol} \mathrm{min}^{-1} \mathrm{mg}^{-1} \mathrm{protein}^{2}\right.\end{array}$ \\
\hline ICGV 86699 & $2.32 \pm 0.07^{\mathrm{ab}}$ & $0.22 \pm 0.002^{\mathrm{b}}$ \\
ICGV 86031 & $2.11 \pm 0.05^{\mathrm{ab}}$ & $0.19 \pm 0.002^{\mathrm{bc}}$ \\
ICG 2271 & $1.78 \pm 0.02^{\mathrm{bc}}$ & $0.20 \pm 0.003^{\mathrm{b}}$ \\
ICG 1697 & $1.94 \pm 0.04^{\mathrm{bc}}$ & $0.18 \pm 0.002^{\mathrm{bc}}$ \\
JL 24 & $3.26 \pm 0.08^{\mathrm{a}}$ & $0.41 \pm 0.005^{\mathrm{a}}$ \\
\hline
\end{tabular}

Values (Mean $\pm \mathrm{SD}$ ) with similar letters within a column do not differ significantly at $p \leq 0.05$ (Tukey's HSD test). 


\subsubsection{Total serine protease and trypsin activity}

Lower total serine protease activity was observed in insects fed on genotypes ICGV $86031\left(\mathrm{~F}_{4,14}=21.7\right)$, ICG $2271\left(\mathrm{~F}_{4,14}=23.1\right)$ and ICG $1697\left(\mathrm{~F}_{4,14}=12.9\right)$ than those fed on 'JL 24' $\left(\mathrm{F}_{4,14}=21.3\right)(p<0.05)$ (Table 3). Similarly, the trypsin activity was significantly lower in insects fed on insect resistant genotypes $\left(\mathrm{F}_{4,14}=10.2,11.1,13.8\right.$ and 6.2, respectively, for ICGV 86699, ICGV 86031, ICG 2271 and ICG 1697, $p<0.05$ ) than in the insects fed on the susceptible check, 'JL 24 '.

\subsubsection{GST and EST activity}

Significantly greater GST activity was observed in insects fed on genotypes ICGV 86699, ICGV 86031, ICG 2271 and ICG $1697\left(\mathrm{~F}_{4,14}=22.1,18.2\right.$ and 12.8, respectively, $p<0.05$ ) than those fed on 'JL 24' (Table 4). The EST activity in insects fed on ICGV 86699, ICGV 86031, ICG 2271 and ICG 1697 was significantly lower $\left(\mathrm{F}_{4,14}=\right.$ 9.5, 9.0 and 11.5 , respectively, $p<0.05)$ than the insects fed on the JL 24.

\subsubsection{Total protein content}

Insect pests exhibited differential protein in insect resistant and susceptible genotypes. The protein content of the insects fed on genotypes ICGV 86699, ICGV
86031, ICG 2271, and ICG 1697 did not differ significantly $\left(7.43,8.22,8.70\right.$ and $9.01 \mathrm{mg} \mathrm{ml}^{-1}$, respectively), however, it was significantly lower in the insects fed on the susceptible check, 'JL 24' (12.7 $\mathrm{mg} \mathrm{ml}^{-1}$ ) (Table 5).

\section{DISCUSSION}

The toxic plant secondary metabolites are important weapons employed by plants against insects. The main mode of action of these metabolites is through the antibiosis mechanism, when ingested, these metabolites have detrimental effects on insects and reduce insect growth and development. The low nutritional quality of plant tissues, proteinase inhibitors and other metabolites are some of the antibiosis factors (Bhonwong et al., 2009; Barbehenn et al., 2010; War et al., 2013). These factors affect the insect food intake and its consumption and utilization by insect pests. The antibiosis and antixenosis plant defences against insect pests can be determined by studying the consumption, digestion and utilization of insects fed with specific host plants (Devetak et al., 2013). Imbalance in insect's food constituents will have drastic effects on its growth and development. Nitrogen content of plant tissues is an important limiting factor for growth and development of insect herbivores (Zhong-xian et al., 2007). Since plant tissues are the main source of nutrients for insects, their availability depends on the amount of food ingested and how efficiently it has been converted to body matter.

Table 4: GST and EST activities of Helicoverpa armigera larvae fed on resistant and susceptible groundnut genotypes

\begin{tabular}{|c|c|c|}
\hline Genotypes & $\begin{array}{l}\text { GST } \\
\left(\mu \mathrm{mol} \mathrm{CDNB} \min ^{-1} \mathrm{mg}^{-1} \text { protein }\right)\end{array}$ & $\begin{array}{l}\text { EST } \\
\left.\text { ( } \mu \mathrm{mol} 1 \text {-napthol } \mathrm{min}^{-1} \mathrm{mg}^{-1} \text { protein }\right)\end{array}$ \\
\hline ICGV 86699 & $1.91 \pm 0.01^{\mathrm{a}}$ & $0.29 \pm 0.004^{\mathrm{a}}$ \\
\hline ICGV 86031 & $1.88 \pm 0.03^{\mathrm{a}}$ & $0.27 \pm 0.004^{\mathrm{a}}$ \\
\hline ICG 2271 & $1.86 \pm 0.04^{\mathrm{a}}$ & $0.31 \pm 0.006^{\mathrm{ab}}$ \\
\hline ICG 1697 & $1.52 \pm 0.07^{\mathrm{a}}$ & $0.30 \pm 0.003^{\mathrm{a}}$ \\
\hline JL 24 & $1.02 \pm 0.03^{\mathrm{a}}$ & $0.39 \pm 0.006^{\mathrm{a}}$ \\
\hline
\end{tabular}

Values (Mean \pm SD) followed by same letter(s) within a column are not significantly different at $p \leq 0.05$ (Tukeys HSD test).

Table 5:Total protein content $\left(\mathrm{mg} \mathrm{ml}^{-1}\right)$ of Helicoverpa armigera larvae fed on fed on resistant and susceptible groundnut genotypes

\begin{tabular}{lc}
\hline Genotypes & Protein content $\left(\mathrm{mg} \mathrm{ml}^{-1}\right)$ \\
\hline ICGV 86699 & $7.43 \pm 0.4^{\mathrm{a}}$ \\
ICGV 86031 & $8.22 \pm 0.2^{\mathrm{a}}$ \\
ICG 2271 & $8.70 \pm 0.3^{\mathrm{a}}$ \\
ICG 1697 & $9.01 \pm 0.2^{\mathrm{a}}$ \\
JL 24 & $12.7 \pm 1.3^{\mathrm{b}}$ \\
\hline
\end{tabular}

Values (mean \pm SD) followed by same followed by letter(s) within a column are not significantly different at $p \leq 0.05$ (Tukey's HSD test). 
Our results showed that $\mathrm{AD}, \mathrm{CI}, \mathrm{ECI}$, and ECD were reduced in $H$. armigera larvae fed on insect-resistant groundnut genotypes and were considerably lower than the insects fed on JL 24. The reduced consumption and utilization of food by $H$. armigera can be attributed to the antibiosis effect of the constitutively produced secondary metabolites including flavonoids, tannins and some defensive proteins (Grayer et al., 1992; Stevenson et al., 1993; Senguttuvan \& Sujatha, 2000; Rao, 2003; War et al., 2013). Antibiosis is one of the important modes of host plant resistance against insects that affects the oviposition, survival and growth and development of the target pests (Sharma \& Norris, 1991; Sharma et al., 2005; Sujana et al., 2008; Ansari et al., 2011). We observed that even though the consumption index of $\mathrm{H}$. armigera was high in some of the insect resistant genotypes such as ICG 1697, ICG 2271 and ICGV 86031, the ECI and ECD were significantly less. This clearly showed that the plant defensive traits pertaining to antibiosis such as toxic secondary metabolites occur in these genotypes. The ingested plant allelochemicals affect the insect's physiological and biochemical traits that in turn impact the post-ingestive nutrient utilization by the pest (Sharma \& Norris, 1991; Hasan \& Ansari, 2011; Ansari et al., 2011; War et al., 2013). Further, insects excrete some of the plant toxic chemicals along with the faecal matter, which in turn, results in reduced efficiency of food utilization. The results showing the differential responses of insects in ingesting the food material, digestion efficiency and conversion of the ingested food into body matter can be used as important indicators for identifying the host plant resistance against insect pests (Sharma \& Norris, 1991; Yazdanfar et al., 2015).

The digestive and the detoxifying enzymes in insect pests showed a differential response on insect resistant and susceptible groundnut genotypes. Serine protease and trypsin activities were reduced in insects fed on the resistant genotypes. This could be attributed to the higher amounts of toxic plant secondary metabolites and/or protease inhibitors in insect resistant genotypes than the susceptible genotype. Reduced serine protease and trypsin activities in insects fed on insect resistant genotypes can be attributed to the antibiosis mechanism of resistance in plants mediated by the toxic secondary metabolites. Further, some plant antioxidative enzymes such as peroxidases are directly toxic to insect pests (Barbehenn et al., 2010). It has also been reported that $H$. armigera larvae when fed on a diet containing plant secondary metabolites show reduced serine protease and trypsin activities (War et al., 2013). Reduced protein digestion, thereby, low levels of amino acids result in reduced growth and developments in insects (Lawrence \& Koundal, 2002; Azzouz et al., 2005).
Insect detoxifying enzymes such as GST and EST convert plant allelochemicals into non-toxic or low toxic compounds (Leszczynski \& Dixon, 1992; Yang et al., 2005; War et al., 2013). These enzymes are induced in insects in response to plant metabolites. Increased activities of GST were observed in insects fed on resistant genotypes as compared to the ones fed on the susceptible genotype JL 24. The higher toxicity of the compounds is attributed to the higher toxicity of the plant toxic secondary metabolites in the insect resistant genotypes (War et al., 2013). In barley, aphid Sitobion avenae (Fabricius, 1775) showed increased levels of GST when fed on plants with greater phenolic content (Leszczynski \& Dixon, 1992). The EST activity did not differ significantly in insects fed on the insect resistant genotypes but was significantly higher in the insects fed on the susceptible genotype, JL 24. The higher levels of toxic secondary metabolites in resistant genotypes than the susceptible genotype might have led to the reduced activity of the EST in insects. ESTs are directly involved in the hydroxylation of toxic plant secondary metabolites and insecticides to less toxic compounds (Yang et al., 2005). Positive correlation has been observed in insect midgut serine proteases, trypsin and GST and larval mass and survival (War et al., 2013). Therefore, plant toxic compounds in resistant genotypes that led to the decrease in the levels of these enzymes could be used as important biochemical markers for plant resistance. Myzus persicae (Sulzer, 1776) exhibited higher levels of GSTs when fed on brassicaceous host plants containing toxic plant metabolites such as glucosinolates and isothiocyanates (Francis et al., 2005). H. armigera fed on artificial diet containing plant toxic metabolites showed higher levels of GST, which has been attributed to the fact that the insect is trying to adapt to the plant toxins (War et al., 2013). They further reported a negative correlation between EST activity and larval growth in $H$. armigera. The total protein content of the larvae fed on insect resistant plants was significantly lower than the larvae fed on the susceptible genotype, JL 24 . Reduced protein levels could have resulted from the toxic effects of the plants metabolites on serine proteases, trypsin and other enzymes. Further, plant protease inhibitors and other antinutritional components are some of the important factors that affect protein synthesis in insects (War et al., 2013). Further, essential amino acid reduction drastically affects the insect growth and development (Chen et al., 2005).

It has been reported that $S$. litura larvae fed on banana leaves showed reduced growth and development, digestibility and consumption rate of plant tissues, however, they exhibited a high conversion efficiency of the ingested food with a high rate of conversion of the digested food. This shows that that the insects compensated for the 
nutrient intake from the limited plant tissues by more efficiently utilizing the host plant tissues (Zhu et al., 2005). The digestion of the plant tissues by insect pests depends on the activities of various enzymes including serine proteases, trypsin, and others. Several factors affect the AD, CI, $\mathrm{ECI}$, and ECD in insect-plant interaction and it is practically difficult to determine the exact "cause" and "effect" responses of these parameters. The questions that arise here are, is it because of low digestibility that the insects eat low or is it that the digestibility is low as the insect eats more? The efficiency parameters involved in host plant feeding by insect pests are physiologically closely related. Though the factors responsible for the efficient conversion of the digested food are still largely unknown, role of shifts in food selection, insect digestive physiology, body composition and metabolic rates can't be ruled out. It is very important to understanding the basic principles of nutritional ecology to identify the host plant resistance against insect pests.

\section{CONCLUSION}

This study determined that the AD, CI, ECI, and ECD in $H$. armigera larvae were significantly reduced when fed with the insect-resistant groundnut genotypes. Though high consumption index was observed in some genotypes (ICG 1697, ICG 2271 and ICGV 86031), the lower ECI and ECD, reduced activities of digestive enzymes and increased detoxifying enzyme activities can be attributed to strong antibiosis mechanism of resistance in these genotypes. This study shows that host plant diet directly affects the digestive plasticity, which in turn, influences the development of insect pests including Helicoverpa armigera. The information derived from this study would be useful to understand the adaptation of insect pests to various genotypes/host plants and the co-evolution between the insect pests and their host plants.

\section{REFERENCES}

Ansari M.S., Hasan F., Ahmad N. (2011). Influence of various host plants on the consumption and utilization of food by Pieris brassicae (Linn.). Bulletin of Entomological Research, https://doi.org/10.1017/S000748531100054X

Armes N.J., Bond G.S., Cooter R.J. (1992). The laboratory culture and development of Helicoverpa armigera. Natural Resources Institute Bulletin, 5.

Azzouz H., Cherqui A., Campan E.D.M., Rahbé Y., Duport G., Jouanin L., Kaiser L., Giordanengo P. (2005). Effects of plant protease inhibitors, oryzacystatin I and soybean BowmanBirk inhibitor, on the aphid Macrosiphum euphorbiae (Homoptera, Aphididae) and its parasitoid Aphelinus abdomina- lis (Hymenoptera, Aphelinidae). Journal of Insect Physiology, 51, 75-86. https://doi.org/10.1016/j.jinsphys.2004.11.010

Barbehenn R., Dukatz C., Holt C., Reese A., Martiskainen O., Salminen J.P., Yip L., Tran L. Constable C.P. (2010). Feeding on poplar leaves by caterpillars potentiates foliar peroxidase action in their guts and increase plant resistance. Oecologia, 164, 993-1004. https://doi.org/10.1007/s00442-010-1733-y

Bhonwong, A., Stout, M.J., Attajarusit, J., Tantasawat P. (2009). Defensive role of tomato Polyphenol oxidase against cotton bollworm (Helicoverpa armigera) and Beet armyworm (Spodoptera exigua). Journal of Chemical Ecology, 35, 28-38. https://doi.org/10.1007/s10886-008-9571-7

Bohinc, T., Hrastar, R., Košir I.Z., Trdan, S. (2013). Association between glucosinolate concentration and injuries caused by cabbage stink bugs Eurydema spp. (Heteroptera: Pentatomidae) on different Brassicas. Acta Scientiarum Agronomy, 35(1), 1-8. https://doi.org/10.4025/actasciagron.v35i1.15622

Chen, H., Wilkerson, C.G., Kuchar, J.A., Phinney, B.S., Howe, G.A. (2005). Jasmonate-inducible plant enzymes degrade essential amino acids in the herbivore midgut. Proceedings of National Academy of Sciences USA, 102, 19237-19242. https://doi.org/10.1073/pnas.0509026102

Devetak, M., Bohinc, T., \& Trdan, S. (2013). Natural resistance of ten cabbage genotypes to cabbage moth (Mamestra brassicae [L.]) attack under field conditions. International journal of food, agriculture \& environment, 11(3\&4), 908-914.

Dwivedi, S.L., Amin, P.W., Rasheedunisa, Nigam, S.N., Nagabushanam G.V.S., Rao V.R., Gibbson R.W. (1986). Genetic analysis of trichome characters associated with resistance to jassid (Empoasca kerri Pruthi) in Peanut. Peanut Science, 13, 15-18. https://doi.org/10.3146/i0095-3679-13-1-5

Francis, F., Vanhaelen, N., Haubruge, E. (2005). Glutathione Stransferases in the adaptation to plant secondary metabolites in the Myzus persicae aphid. Archives of Insect Biochemistry and Physiology, 58, 166-174. https://doi.org/10.1002/ $\operatorname{arch} .20049$

Grayer, R.J., Kimmins, F.M., Padgham, D.E., Harborne, J.B., Ranga Rao, D.V. (1992). Condensed tannin levels and resistance in groundnuts (Arachis hypogoea (L.) against Aphis craccivora (Koch). Phytochemistry, 31, 3795-3799. https://doi. org/10.1016/S0031-9422(00)97530-7

Habig, W.H., Pabst, M.J., Jakoby, W.B. (1974). Glutathione-Stransferases. The first enzymatic step in mercapturic acid formation. Journal of Biological Chemistry, 249, 7130-7139. https://doi.org/10.1016/S0021-9258(19)42083-8

Hasan, F., Ansari, M.S. (2011). Population growth of Pieris brassicae (L.) (Lepidoptera: Pieridae) on different cole crops under laboratory conditions. Journal of Pest Science, 84,179-186. https://doi.org/10.1007/s10340-010-0339-9

He, J., Chen, F., Chen, S., Lv, G., Deng, Y., Fang, Z., Guan, Z., H,e C. (2011). Chrysanthemum leaf epidermal surface morphology and antioxidant and defense enzyme activity in response to aphid infestation. Journal of Plant Physiology, 168, 687-693. https://doi.org/10.1016/j.jplph.2010.10.009

Hegedus, D., Baldwin, D., O'Grady, M., Braun, L., Gleddie, S., Sharpe, A., Lydiate, D., Erlandson, M. (2003). Midgut proteases from Mamestra configurata (Lepidoptera: Noctuidae) larvae: characterization, cDNA cloning, and expressed se- 
quence tag analysis. Archives of Insect Biochemistry and Physiology, 53, 30-47. https://doi.org/10.1002/arch.10084

Howe, G.A., Jander, G. (2008). Plant immunity to herbivores. Annual Reviews Plant Biology, 59, 41-66. https://doi.org/10.1146/ annurev.arplant.59.032607.092825

Isman, M.B. (2006). The role of botanical insecticides, deterrents and repellents in modern agriculture and an increasingly regulated world. Annual Reviews in Entomology, 51, 45-66. https://doi.org/10.1146/annurev.ento.51.110104.151146

Karban R. (2011). The ecology and evolution of induced resistance against herbivores. Functional Ecology, 25, 339-347. https://doi.org/10.1111/j.1365-2435.2010.01789.x

Lawrence, P.K., Koundal, K.R. (2002). Plant protease inhibitors in control of phytophagous insects. EJB Electron Journal of Biotechnology, 5, 93-109. https://doi.org/10.2225/vol5-issue1fulltext-3

Leszczynski, B., Dixon, A.F.G. (1992). Resistance of cereals to aphids: The interaction between hydroxamic acids and glutathione S-transferases in the grain aphid Sitobion avenae (F.) (Hom., Aphididae). Journal of Applied Entomology, 113, 61-67. https://doi.org/10.1111/j.1439-0418.1992.tb00636.x

Lowery, O.H., Rosebrough, N.I., Farr, A.L., Randall, R.J. (1951). Protein measurement with the folin phenol reagent. Journal of Biological Chemistry, 193, 265-275. https://doi.org/10.1016/ S0021-9258(19)52451-6

Perlmann, G., Lorand, L. (1970). Editors, Proteolytic Enzymes (2nd ed.), Vol. 19 of -Methods in Enzymology (pp. 770-782). Academic Press, New York.

Rao, R.V.S., Sridhar, R., Singh, U., Ranga Rao, G.V. (1998). Biochemical basis in groundnut (Arachis hypogaea) resistant to leafminer (Aproaerema modicella). Indian Journal of Agricultural Sciences, 68(2), 104-109.

Senguttuvan, T., Sujatha, K. (2000). Biochemical basis of resistance in groundnut against leaf miner. International Arachis Newsletter, 20, 69-71.

Sharma, H.C. (2009). Biotechnological Approaches for Pest Management and Ecological Sustainability (pp. 526). CRC Press/Taylor and Francis, New York, USA. https://doi. org/10.1201/9781420088489

Sharma, H.C., Norris, D.M. (1991). Chemical basis of resistance in soya bean to cabbage looper, Trichoplusia ni. Journal of Science Food and Agriculture, 55, 353-364. https://doi. org/10.1002/jsfa.2740550304

Sharma, H.C., Pampathy, G., Dhillon, M.K., Ridsdill-Smith, J.T. (2005). Detached leaf assay to screen for host plant resistance to Helicoverpa armigera. Journal of Economic Entomology, 98(2), 568-576. https://doi.org/10.1093/jee/98.2.568

Sharma, H.C., Sujana, G., Rao, D.M. (2009). Morphological and chemical components of resistance to pod borer, Helicoverpa armigera in wild relatives of pigeonpea. Arthropod-Plant Interactions, 3(3), 151-161. https://doi.org/10.1007/s11829009-9068-5

Sharma, H.C. (2005). Heliothis/Helicoverpa Management: Emerging trends and strategies for future research (pp. 469). New Delhi, India: Oxford and IBH Publishing Co. Pvt.Ltd. https:// doi.org/10.1201/9781482280340

Sharma, H.C. (2007). Host plant resistance: Modern approaches and limitations. Indian Journal Plant Protection, 35, 179-184.

Sharma, H.C., Pampathy, G., Dwivedi, S.L., Reddy, L.J. (2003).
Mechanism and diversity of resistance to insect pests in wild relatives of groundnut. Journal of Economic Entomology, 96(6), 1886-1897. https://doi.org/10.1093/jee/96.6.1886

Smith, C.M. (2005). Plant Resistance to Arthropods: Molecular and Conventional Approaches. Dordrecht, The Netherlands: Springer Verlag. https://doi.org/10.1007/1-4020-3702-3

Stevenson, P.C., Blaney, W.L., Simmonds, M.S.J., Wightman, J.A. (1993). The identification and characterization of resistance in wild species of Arachis to Spodoptera litura (Lepidoptera: Noctuidae). Bulletin of Entomological Research, 83, 421-429. https://doi.org/10.1017/S0007485300029333

Sujana, G., Sharma, H.C., Rao, D.M. (2008). Antixenosis and antibiosis components of resistance to pod borer Helicoverpa armigera in wild relatives of pigeon pea. International Journal of Tropical Insect Science, 28, 191-200.

War, A.R., Paulraj, M.G., Ahmad, T., Buhroo, A.A., Hussain, B., Ignacimuthu, S., Sharma, H.C. (2012). Mechanisms of plant defense against insect herbivores. Plant Signaling and Behavior, 7(10), 1306-1320. https://doi.org/10.4161/psb.21663

War, A.R., Paulraj, M.G., Hussain, B., Buhroo, A.A., Ignacimuthu, S., Sharma, H.C. (2013). Effect of plant secondary metabolites on Helicoverpa armigera. Journal of Pest Science, 86, 399-408. https://doi.org/10.1007/s10340-013-0485-y

War, A.R., Sharma, S.P., Sharma, H.C. (2016). Differential induction of flavonoids in groundnut in response to Helicoverpa armigera and Aphis craccivora infestation. International Journal of Insect Science, 8, 55-64. https://doi.org/10.4137/IJIS. S39619

War, A.R., Paulraj, M.G., War, M.Y., Ignacimuthu, S. (2011). Jasmonic acid- mediated induced resistance in groundnut (Arachis hypogaea L.) against Helicoverpa armigera (Hubner) (Lepidoptera: Noctuidae). Journal of Plant Growth Regulation, 30, 512-523. https://doi.org/10.1007/s00344-011-9213-0

War, A.R., Sharma, H.C. (2014). Effect of jasmonic acid and salicylic acid induced resistance in groundnut on Helicoverpa armigera (Hub.). Physiological Entomology, 39(2), 136-142.

Waldbauer, G.P. (1968). The consumption and utilization of food by insects. Advances in Insect Physiology, 5, 229-288. https:// doi.org/10.1016/S0065-2806(08)60230-1

Yang, Z., Zhang, F., He, Q., He, G. (2005). Molecular dynamics of detoxification and toxin-tolerance genes in brown plant hopper (Nilaparvata lugens Stal., Homoptera: Delphacidae) feeding on resistant rice plants. Archives of Insect Biochemistry and Physiology, 59, 59-66. https://doi.org/10.1002/arch.20055

Yazdanfar, H., Daryaei, M.G., Sendi, J.J., Ghobri, H., Valizdeh, B. (2015). Effects of various host plants on nutritional indices and some biochemical compounds in green oak leaf roller, Tortrix viridana L. (Lepidoptera: Tortricidae). Journal of Entomological and Acarological Research, 47(4954), 98-102. https://doi.org/10.4081/jear.2015.4954

Zhong-xian, L., Xiao-ping, Y., Heong, K.L., Cui, H. (2007). Effect of nitrogen fertilizer on herbivores and its stimulation to major. Rice Science, 14, 56-66. https://doi.org/10.1016/S16726308(07)60009-2

Zhu, J.H., Zhang, F.P., Ren, H.G. (2005). Development and nutrition of Prodenia litura on four food plants. Chinese Bulletin of Entomology, 42, 643-646. 